\title{
PENGARUH PEMBELAJARAN KOOPERATIF TIPE STAD \\ MENGGUNAKAN PETA KONSEP TERHADAP \\ HASIL BELAJAR KIMIA SISWA SMA KELAS X \\ PADA MATERI LARUTAN ELEKTROLIT \\ DAN NON ELEKTROLIT
}

\section{THE EFFECT OF STAD TYPE COOPERATIVE LEARNING USING CONCEPT MAP ON STUDENTS' CHEMISTRY LEARNING OUTCOMES OF X GRADE SMA ON ELECTROLYTE AND NON ELECTROLYTE SOLUTION MATERIALS}

\author{
Eva Pratiwi Pane*, Fine Eirene Siahaan \\ Program Studi Pendidikan Kimia Universitas HKBP Nommensen Pematangsiantar \\ *Corresponding author: evapratiwi2607@gmail.com
}

\begin{abstract}
ABSTRAK
Penelitian ini bertujuan untuk mengetahui peningkatan hasil belajar siswa pada materi Larutan Elektrolit dan Non Elektrolit Kelas X dengan menggunakan penerapan model pembelajaran kooperatif tipe STAD menggunakan peta konsep di SMA Surya Pematangsiantar T.P. 2019/2020 dan untuk menyelidiki peningkatan hasil belajar siswa yang mendapat pembelajaran kooperatif tipe STAD menggunakan peta konsep. Populasi dalam penelitian ini adalah seluruh siswa kelas X SMA Surya Pematangsiantar dan sampel terdiri dari dua kelas dimana kelas pertama sebagai kelas eksperimen dan kelas kedua sebagai kelas kontrol dengan teknik pengambilan sampel yang dilakukan adalah teknik sampling random. Hasil pre test pada kelas eksperimen diperoleh nilai terendah 20 dan nilai tertinggi 50 dengan nilai rata- rata 33,50 dan standar deviasi 9,14 sedangkan untuk nilai post test diperoleh nilai terendah 60 dan nilai tertinggi 95 dengan nilai rata- rata 75,87dan standar deviasi 9,67. Hasil belajar siswa yang diajarkan dengan model pembelajaran kooperatif tipe STAD menggunakan peta konsep lebih tinggi dibandingkan dengan hasil belajar siswa yang diajarkan dengan pembelajaran konvensional sebesar 40,89\%. Hal ini dapat membuktikan bahwa model pembelajaran kooperatif tipe STAD menggunakan peta konsep dapat membuat siswa lebih aktif sehinggga termotivasi untuk belajar sehingga hasil belajarnya akan meningkat. Uji hipotesis diperoleh bahwa $t$ hitung $>t$ tabel yaitu $6,995>1,994$ pada taraf $\alpha=0,05$ yang menunjukkan bahwa hasil belajar siswa yang mendapat pembelajaran kooperatif tipe STAD menggunakan peta konsep lebih tinggi dari hasil belajar siswa yang mendapat pembelajaran konvensional pada pokok bahasan Larutan elektrolit dan non elektrolit.
\end{abstract}

Kata kunci: STAD; peta konsep; elektrolit; non eletrolit.

\section{ABSTRACT}

This study aims to determine the improvement of student learning outcomes in the material of Electrolyte and Non-Electrolyte Solutions Class X by using the implementation of the STAD type cooperative learning model using a concept map at SMA Surya Pematang siantar T.P. 2019/2020 and to investigate the improvement of student learning outcomes who received STAD type cooperative learning using Concept Maps. The population in this study were all students of class X SMA Surya Pematangsiantar and the sample consisted of two classes where the first class was the experimental class and the second class was the control class. The sampling technique used was random sampling. The results of the pre test in the experimental class obtained the lowest score of 20 and the highest score of 50 with an average value of 33.50 and a standard deviation of 9.14 while the post test score 
obtained the lowest score of 60 and the highest value of 95 with an average value of 75.87 and a standard deviation 9.67. The learning outcomes of students taught with the STAD type cooperative learning model using concept maps were higher than those of students taught with conventional learning of 40.89\%. This can prove that the STAD type cooperative learning model using concept maps can make students more active so that they are motivated to learn so that their learning outcomes will increase. Hypothesis testing is obtained that $t$ count $>t$ table is $6.995>1.994$ at level $=$ 0.05 which indicates that the learning outcomes of students who receive STAD type cooperative learning using concept maps are higher than the learning outcomes of students who receive conventional learning on the subject Electrolyte solution and non-electrolyte.

Keywords: STAD; concept map; electrolyte; non-electrolyte.

\section{PENDAHULUAN}

Pendidikan adalah usaha sadar dan terencana untuk mewujudkan suasana belajar dan proses pembelajaran agar peserta didik secara aktif mengembangkan potensi dirinya. Belajar adalah proses perubahan perilaku berkat pengalaman dan latihan. Artinya, tujuan kegiatan adalah perubahan tingkah laku baik yang menyangkut pengetahuan, keterampilan maupun sikap, bahkan meliputi segenap aspek organisasi atau pribadi (Djamarah, 2006).

Ilmu kimia merupakan ilmu yang diperoleh dan dikembangkan berdasarkan eksperimen yang mencari jawaban atas pertanyaan apa, mengapa, dan bagaimana gejala-gejala alam, khususnya yang berkaitan dengan zat. Salah satu penyebab rendahnya hasil belajar kimia siswa adalah banyaknya siswa yang beranggapan bahwa pelajaran kimia sulit dipelajari. Dalam pelaksanaan proses pengajaran kimia selama ini menunjukkan bahwa sebagian besar siswa tampak kurang berminat, kurang bergairah dan cenderung tidak aktif. Hal ini ditunjukkan oleh sikap yang kurang antusias ketika pelajaran akan berlangsung, rendahnya respon umpan balik dari siswa terhadap pertanyaan dan penjelasan guru serta pemusatan perhatian yang kurang.

Apabila keseluruhan materi kimia ini diajarkan guru secara konvensional dan tidak ada variasi, siswa tidak akan tertarik pada pelajaran kimia sehingga siswa malas untuk mempelajarinya dan kemungkinan besar siswa tidak akan memahami pelajaran tersebut dengan baik yang dapat menyebabkan hasil belajar kimia rendah. Berdasarkan kondisi diatas, untuk mengantisipasi hal tersebut guru perlu mengembangkan pendekatan pembelajaran yang dianggap sesuai dan bervariasi sehingga siswa senang dalam mempelajari materi kimia karena rasa senang dalam belajar merupakan kunci sukses dalam menguasi pelajaran secara utuh dan baik, selain itu melalui pendekatan tersebut siswa dilibatkan secara aktif dalam kegiatan pembelajaran untuk menemukan dan menerapkan ide-ide terhadap suatu konsep kimia.

Salah satu model pembelajaran yang dapat diterapkan dalam proses belajar mengajar kimia adalah model pembelajaran kooperatif tipe STAD menggunakan peta konsep. Teknik STAD menggunakan peta konsep ini memberikan kesempatan kepada siswa untuk saling membagikan ideide dan mempertimbangkan jawaban yang paling tepat. Selain itu teknik ini juga mendorong siswa untuk meningkatkan semangat kerja sama mereka (Lie, 2007). Pembelajaran kooperatif tipe STAD menggunakan peta konsep ini pernah diteliti oleh beberapa peneliti sebelumnya, antara lain: Ika Yuliana, (2008) hasil penelitiannya mengenai kooperatif tipe STAD menggunakan peta konsep menyatakan bahwa terdapat peningkatan hasil belajar siswa yang signifikan sebesar 19,8\% setelah diterapkan model pembelajaran kooperatif tipe STAD menggunakan peta konsep. Peneliti yang lain yaitu Suhariati, (2009) menyatakan bahwa terdapat peningkatan hasil belajar siswa sebesar 19,23\%.

Peta konsep menggambarkan jalinan antar konsep yang dinyatakan dalam bentuk istilah. Konsep-konsep dijalin secara bermakna dengan kata-kata penghubung sehingga dapat membentuk proposisi. Dengan menggunakan peta konsep ini dalam pembelajaran maka dapat diperkirakan kedalamam dan keluasan konsep yang perlu diajarkan kepada siswa sehingga apa yang dipelajari siswa akan lebih bermakna, lebih mudah diingat dan lebih dipahami.

Menurut Gagne menyatakan bahwa penggunaan peta konsep merupakan satu stategi kognitif yang mudah diamalkan. Pelajar akan mempelajari bahan yang diajar dengan cepat apabila pengajaran dibuat dalam bentuk kumpulan yang berbentuk gambar atau bentuk perkataan tersusun. 
Materi larutan elektrolit dan non elektrolit merupakan materi yang sangat erat kaitannnya dengan kehidupan sehari-hari. Namun, pemahaman siswa pada pokok bahasan tersebut masih rendah, hal ini mungkin disebabkan karena guru didalam menjelaskan pokok bahasan tersebut belum menggunakan strategi pengajaran yang tepat. Selama ini pengajaran larutan elektrolit dan non elektrolit banyak menggunakan metode ekspositori (ceramah), akibatnya hasil belajar yang didapatkan kurang memuaskan. Untuk membantu siswa memudahkan menguasai materi Larutan elektrolit dan non elektrolit , maka pembelajarannya sangat tepat jika dilakukan dengan pembelajaran kooperatif tipe STAD menggunakan peta konsep. Pada pembelajaran kooperatif tipe STAD menggunakan peta konsep siswa yang mempunyai kemampuan tinggi dapat mengajari siswa yang mempunyai kemampuan rendah dalam melakukan pemecahan masalah terhadap soal sesuai dengan pemahamannya. Kemudian guru dapat mengecek pemahaman siswa dengan menyebut salah satu nomor anggota kelompok untuk menjawab masalah yang diberikan. Oleh karena itu melalui pembelajaran kooperatif tipe STAD menggunakan peta konsep diharapkan siswa mendapat kemudahan mempelajari materi struktur atom dan sistem periodik unsur.

\section{METODE PENELITIAN}

\subsection{Jenis Penelitian}

Penelitian ini menggunakan pendekatan kuantitatif dengan menggunakan metode eksperimen semu (quasi eksperimen) factorial 2 x 2, yang terdiri dari 2 kelas, yaitu kelas eksperimen dan kelas kontrol dengan membuat suatu perlakuan dalam pembelajaran yaitu proses pembelajaran dengan model pembelajaran kooperatif tipe STAD menggunakan peta konsep dan tanpa model pembelajaran kooperatif tipe STAD menggunakan peta konsep.

\subsection{Waktu dan Tempat Penelitian}

Penelitian dilaksanakan di SMA Surya Pematangsiantar. Penelitian ini dilaksanakan pada bulan Maret semester genap tahun ajaran 2018/2019. Populasi dalam penelitian ini adalah seluruh siswa kelas X SMA SMA Surya Pematangsiantar yang berjumlah 105 siswa dalam 3 kelas. Setiap kelas ratarata terdiri 30 siswa.

\subsection{Target/Subjek Penelitian}

Sampel dalam penelitian ini dipilih dengan teknik random sampling dan yang menjadi sampel dalam penelitian ini adalah dua kelas $X$ yaitu satu kelas sebagai kelas ekperimen dan satu kelas sebagai kelas kontrol. Variabel bebas dalam penelitian ini adalah model pembelajaran kooperatif tipe STAD menggunakan peta konsep. Variabel terikat dalam penelitian ini adalah hasil belajar siswa pada materi Larutan Elektrolit dan Non Elektrolit.

\subsection{Prosedur}

Penelitian ini melibatkan dua kelas yaitu kelas eksperimen dan kelas kontrol dimana kedua kelas ini mendapat perlakuan yang berbeda. Kelas ekperimen diberikan model pembelajaran kooperatif tipe STAD menggunakan peta konsep sedangkan kelas kontrol diberikan model pembelajaran konvesional.

Dalam penelitian ini diberikan tes sebanyak dua kali yaitu sebelum perlakuan dan sesudah perlakuan. Tes yang diberikan sebelum perlakuan $\left(T_{1}\right)$ disebut pretest dan tes yang diberikan sesudah perlakuan $\left(T_{2}\right)$ disebut postest. Perbedaan antara $T_{1}$ dan $T_{2}$ yakni $T_{2}-T_{1}$ diasumsikan sebagai efek dari perlakuan. Rancangan penelitian dapat digunakan sebagai berikut:

Tabel 1. Disain penelitian Two-Group (pre-test dan post-test)

\begin{tabular}{cccc}
\hline Kelas & Pre-test & Perlakuan & Post-test \\
\hline Eksperimen & $\mathrm{T}_{1}$ & $\mathrm{X}_{1}$ & $\mathrm{~T}_{2}$ \\
\hline Kontrol & $\mathrm{T}_{1}$ & $\mathrm{X}_{2}$ & $\mathrm{~T}_{2}$ \\
\hline
\end{tabular}

Dimana : $\quad \mathrm{T}_{1}=$ Pre-test

$\mathrm{T}_{2}=$ Post-tes 


$$
\begin{aligned}
\mathrm{X}_{1}= & \text { Perlakuan dengan model pembelajaran kooperatif tipe STAD menggunakan peta } \\
& \text { konsep } \\
\mathrm{X}_{2}= & \text { Perlakuan dengan model pembelajaran konvensional }
\end{aligned}
$$

\subsection{Data, Instrumen, dan Teknik Pengumpulan Data}

Dalam rangka mengolah data ditempuh langkah-langkah sebagai berikut: melaksanakan pretest kepada siswa yang menjadi sampel penelitian, mempersiapkan rencana pembelajaran tentang materi Larutan Elektrolit dan non Elektrolit, mengajar materi dengan menerapkan model pembelajaran kooperatif tipe STAD menggunakan peta konsep dikelas eksperimen dan pembelajaran konvensional di kelas kontrol, melaksanakan post-tes setelah materi selesai diberikan untuk mengetahui gambaran hasil belajar siswa setelah diberi perlakuan, menghitung peningkatan (gain) hasil belajar, menganalisa data dengan melakukan uji statistik dan membuat kesimpulan berdasarkan hasil analisa data.

\subsection{Teknik Analisis Data}

Uji hipotesis yang digunakan dalam penelitian ini adalah uji hipotesis dengan menggunakan ujit pihak kanan (uji t-fisher's) dan peningkatan hasil belajar siswa yang diajar dengan pembelajaran kooperatif tipe STAD menggunakan peta konsep dilihat dengan menggunakan gain (pencapaian).

\section{HASIL DAN PEMBAHASAN}

Berdasarkan hasil pre test pada kelas eksperimen diperoleh nilai terendah 20 dan nilai tertinggi 50 dalam konversi nilai antara 5 - 100 dengan nilai rata- rata 33,50 dan standar deviasi 9,14, sedangkan untuk nilai post test diperoleh nilai terendah 60 dan nilai tertinggi 95 dengan nilai rata- rata 75,87dan standar deviasi 9,67.

Berdasarkan hasil pre test pada kelas kontrol diperoleh nilai terendah 20 dan nilai tertinggi 55 dalam konversi nilai antara 5 - 100 dengan nilai rata- rata 37,25 dan standar deviasi 10,62, sedangkan untuk nilai post test diperoleh nilai terendah 45 dan nilai tertinggi 80 dengan nilai rata- rata 61,87 dan standar deviasi 8,96.

Untuk menguji apakah data yang diperoleh dalam penelitian ini berdistribusi normal atau tidak, maka dapat diuji dengan menggunakan Uji Liliefors dan diperoleh data seperti dinyatakan dalam tabel

\begin{tabular}{|c|c|c|}
\hline Kelas & $\begin{array}{c}\text { Rata- rata } \\
\text { dan Standar Deviasi }\end{array}$ & L Hitung \\
\hline Eksperimen & $\begin{array}{l}\bar{X}_{1}=33,50 \\
S_{1}=9,14\end{array}$ & 0,1230 \\
\hline Kontrol & $\begin{array}{l}X_{1}=37,25 \\
S_{1}=10,62\end{array}$ & 0,0999 \\
\hline
\end{tabular}
2 .

Tabel 2. Hasil Uji Normalitas Pre-Test

Dari data terlihat bahwa data yang diperoleh pada penelitian berdistribusi normal dimana $\mathrm{L}$ hitung lebih besar dari $\mathrm{L}$ tabel 0,1400 dan $\alpha=0,05$.

Tabel 3. Hasil Uji Normalitas Pos-Test

\begin{tabular}{rll}
\hline Kelas & \multicolumn{1}{c}{$\begin{array}{c}\text { Rata- rata } \\
\text { dan Standar Deviasi }\end{array}$} & L Hitung \\
\hline \multirow{2}{*}{ Eksperimen } & $\begin{array}{l}\bar{X}_{1}=75,87 \\
S_{1}=9,67\end{array}$ & 0.0936 \\
\hline
\end{tabular}




$\begin{array}{lll}\text { Kontrol } & \bar{X}_{1}=61,87 & 0,1082 \\ & S_{1}=8,96\end{array}$

Dari data terlihat bahwa data yang diperoleh pada penelitian berdistribusi normal dimana $\mathrm{L}$ hitung lebih besar dari $\mathrm{L}$ tabel 0,1400 dan $\alpha=0,05$.

Untuk hasil perhitungan homogenitas, diperoleh harga $F$ hitung $=1,065$ dan setelah dibandingkan harga $\mathrm{F}$ hitung dengan harga $\mathrm{F}$ tabel pada taraf nyata 0,05 diperoleh $\mathrm{F}$ tabel $=1,71$. Ternyata $\mathrm{F}$ hitung $<\mathrm{F}$ tabel yaitu $1,065<1,71$, ini membuktikan sampel kedua kelompok berasal dari kelompok yang homogen. Hal ini dapat dilihat pada tabel 4.

Tabel 4.Uji Homogenitas gain Ternormalisasi

\begin{tabular}{ccccc}
\hline Kelas & $\bar{X}$ & $\mathbf{S}$ & F hitung tabel & F \\
\hline Eksperimen & 0,626 & 0,162 & 1,065 & 1,71 \\
Kontrol & 0,370 & 0,167 & 1,065 & 1,71 \\
\hline
\end{tabular}

Dari tabel juga dapat dilihat gain untuk kelas eksperimen sebesar $62,6 \%$ dan untuk kelas kontrol sebesar $37,0 \%$.

Telah diketahui bahwa kedua data adalah berdistribusi normal dan mempunyai varian yang sama atau homogen dengan demikian pengujian hipotesis dilakukan melalui uji $\mathrm{t}$ atau melalui uji perbedaan dua rata- rata. Dari perhitungan diperoleh t hitung $=6,995$. Berdasarkan tabel statistik dengan $\mathrm{dk}=78$ dan $\alpha=0,05$ diperoleh $\mathrm{t}$ tabel $=1,994$. Ternyata $\mathrm{t}$ hitung $>\mathrm{t}$ tabel yaitu $6,995>1,994$ dapat dilihat pada tabel.

Berdasarkan data pada tabel hasil uji hipotesis, diperoleh bahwa t hitung $>\mathrm{t}$ tabel yaitu 6,995 > 1,994 yang menunjukkan bahwa hasil belajar siswa yang mendapat pembelajaran kooperatif tipe STAD menggunakan peta konsep lebih tinggi dari hasil belajar siswa yang mendapat Pembelajaran konvensional pada materi Larutan Elektrolit dan Non Elektrolit. Dengan kata lain bahwa pembelajaran kooperatif tipe STAD menggunakan peta konsep lebih efektif dibandingkan dengan pembelajaran konvensional dalam meningkatkan hasil belajar siswa.

Tabel 5. Hasil Uji Hipotesis

\begin{tabular}{clcccc}
\hline \hline Kelas & $\begin{array}{c}\text { Rata- rata dan } \\
\text { Simpangan }\end{array}$ & t hitung & t tabel & $\boldsymbol{\alpha}$ & $\begin{array}{c}\text { dk } \\
\text { Keterangan }\end{array}$ \\
\hline \hline Eksperimen & $\bar{X}_{1}=0,626$ & 6,995 & 1,994 & 0,05 & 78 \\
& $S_{1}=0,162$ & & & & Terima Ha \\
& $\bar{X}_{1}=0,370$ & & & & 78 \\
Kontrol & $S_{1}=0,167$ & 6,995 & 1,994 & 0,05 & $\begin{array}{c}7,0 \\
\end{array}$ \\
& & & & & \\
\hline
\end{tabular}

Berdasarkan penelitian yang telah dilakukan diperoleh bahwa rata- rata nilai kimia siswa pada materi Larutan Elektrolit dan Non Elektrolit yang diajarkan dengan metode pembelajaran kooperatif tipe STAD menggunakan peta konsep lebih tinggi $(x=75,87 \pm 9,67)$ dibandingkan dengan pembelajaran konvensional ( $x=33,50 \pm 9,14$ ). Hal ini membuktikan bahwa pembelajaran kooperatif tipe STAD menggunakan peta konsep dapat meningkatkan hasil belajar kimia pada siswa khususnya pada materi Larutan Elektrolit dan Non Elektrolit. 
Selain itu, kita juga dapat melihat dari hasil perhitungan nilai rata- rata dan pengujian hipotesis. Dari pengujuian hipotesis diperoleh bahwa $\mathrm{t}$ hitung $=6,995 \mathrm{dan} \mathrm{t}$ tabel $=1,994$ (t hitung $>\mathrm{t}$ tabel) pada $\alpha=0,05$ yang menunjukkan bahwa Ho ditolak dan Ha diterima. Hal ini menunjukkan bahwa hasil belajar siswa yang mendapat pembelajaran kooperatif tipe STAD menggunakan peta konsep lebih tinggi dari hasil belajar siswa yang mendapat pembelajaran konvensional pada materi Larutan Elektrolit dan Non Elektrolit di Kelas X SMA Surya Pematangsiantar.

Berbeda dengan pembelajaran konvensional, meskipun guru dapat dengan mudah menguasai kelas dan dapat merangkum atau menjelaskan pokok- pokok materi yang penting dalam waktu singkat, akan tetapi siswa pasif akibatnya siswa hanya akan mendengar dan bertumpu pada apa yang diucapkan oleh guru dan ada juga siswa yang tidak mendengar dan menyimak penjelasan guru dengan baik akibatnya motivasi belajar siswa akan berkurang. Apabila diberi contoh atau permasalahan baru maka siswa akan bingung dan seolah- olah sulit mengembangkan teori dengan contoh yang diberikan. Akibatnya hasil belajar yang diperoleh lebih rendah dibandingkan dengan hasil belajar siswa yang diajarkan dengan menggunakan model pembelajaran kooperatif tipe STAD menggunakan peta konsep.

\section{SIMPULAN DAN SARAN}

\subsection{Simpulan}

berikut :

Berdasarkan hasil penelitian yang telah dilakukan, diambil beberapa kesimpulan sebagai

1. Rata-rata keberhasilan belajar siswa yang diajar dengan model Pembelajaran Kooperatif Tipe STAD menggunakan peta konsep pada materi Larutan Elektrolit dan Non Elektrolit di Kelas X SMA Surya Pematangsiantar adalah $62.6 \%$.

2. Rata-rata keberhasilan belajar siswa yang diajar dengan model Pembelajaran Konvensional pada materi Larutan Elektrolit dan Non Elektrolit di kelas X SMA Surya Pematangsiantar adalah $37.0 \%$.

3. Hasil belajar siswa untuk kelas eksperimen adalah $\left(\overline{X_{1}}=75,87 \pm 9,67\right)$ sedangkan hasil belajar untuk kelas kontrol adalah $\left(\overline{X_{1}}=33,50 \pm 9,14\right)$ dan diperoleh $t_{\text {hitung }}=6,995$ sedangkan $t_{\text {tabel }}=1,994$ pada taraf signifikansi $(\alpha=0.05)$ dan $\mathrm{db}=78$.

\subsection{Saran}

Berdasarkan hasil analisis data, maka disarankan beberapa hal sebagai berikut:

1. Kepada guru- guru khususnya guru bidang studi kimia untuk dapat menggunakan model pembelajaran kooperatif tipe STAD menggunakan peta konsep karena dapat membantu siswa untuk menguasai materi pelajaran.

2. Pada peneliti selanjutnya agar dapat meneliti sekolah- sekolah lain dengan pokok bahasan yang berbeda sehingga dapat dijadikan sebagi studi perbandingan guru untukl meningkatkan kualitas pendidikan khususnya mata pelajaran kimia.

\section{DAFTAR PUSTAKA}

Arikunto, Suharsimi, (2003), Dasar- dasar Evaluasi Pendidikan, Bumi Akasara, Jakarta.

Dalyono, M, (2007), Psikologi Pendidikan, Rineke Cipta, Jakarta

Dimyanti dan Mudjiono, (2003), Belajar dan Pembelajaran, Rineka Cipta, Jakarta.

Djamarah, S.B., (2002), Strategi Belajar Mengajar, Rineka Cipta, Jakarta.

Lie, A., (2007), Cooperative Learning Mempraktikkan Cooperative Learning di RuangRuang Kelas, Grasindo, Jakarta.

Purba, Michael, (2006), Kimia Untuk SMA Kelas XI Semester 2, Erlangga, Jakarta.

Sagala, S,(2006), Konsep dan Makna Pembelajaran Untuk Membantu Memecahkan Problematika Belajar dan Mengajar. Penerbit Alfabeta, Bandung.

Slameto, (2003), Belajar dan Faktor-faktor Yang Mempengaruhinya, Rineka Cipta, Jakarta.

Sudarmo, Unggul., (2006), Kimia Untuk SMA Kelas XI, Phibieta, Jakarta.

Sudjana, M.A., (2005), Metode Statistika, Tarsito, Bandung. 
Suhariati, (2009), Pengaruh Pembelajaran Kooperatif Tipe Number Head Together (NHT) Terhadap Hasil Belajar Siswa., Skripsi, FMIPA, Unimed, Medan.

Trianto, (2007), Model-model Pembelajaran Inovatif Berorientasi Konstruktivitik, Prestasi Pustaka, Jakarta.

Utami, Budi., (2009), Kimia untuk SMA dan MA Kelas X, Pusat Perbukuan Departemen Pendidikan Nasional Tahun 2009, Jakarta.

Yuliana, Ika., (2008), Pengaruh Pembelajaran Kooperatif Tipe NHT Terhadap Hasil Belajar Siswa Pada Materi Pokok Struktur Atom Kelas XI Sma Negeri 14 Medan Tahun Ajaran 2008/2009., Skripsi, FMIPA, Unimed, Medan. 